\title{
A Symposium on Donor-Specific Antibodies after Transplantation
}

\section{Introduction}

\author{
Jeffrey L. Platt \\ Transplantation Biology, Departments of Surgery and \\ Microbiology and Immunology, BSRB, University of Michigan, USA
}

The paper by Ho et al. (1) in this issue of Pediatric Transplantation launches a symposium on donor-specific antibodies after transplantation. During the 50-or-so-year history of clinical transplantation, no subject has commanded greater attention and provoked greater controversy. The attention to donor-specific antibodies derives in part from the use of these unique reagents to define the major histocompatibility locus (2) and use in tissue typing (3) and in part from use of sera of a potential recipient for crossmatching to prevent immediate rejection (4). Today, donor-specific antibodies might offer insight into the immunological responsiveness of a recipient against their graft and hence a warning about the risk of rejection.

Donor-specific antibodies also spark controversy. Some believe these antibodies cause the most important types of rejection, while others believe they merely mark the immune or inflammatory condition. Some have found these antibodies can modify grafts or the immune response to grafts that actually protects against rejection. Controversy about whether donor-specific antibodies are effectors or just markers of immunity to a graft is of more than academic import, as one now can apply specific but also expensive and potentially toxic therapies to suppress or deplete these antibodies.

Whether and to what extent donor-specific antibodies elicited by transplantation determine the fate of grafts remains to be settled. The complexity of this question and the difficulties faced by those who have tried to answer it were critically and thoroughly summarized by Stetson in 1963 (5). Part of the complexity stems from the fact that antibodies can protect as well as injure grafts (6) and in part from the fact that organ grafts are far more susceptible to antibodymediated injury than cell and tissue grafts (7). Opposing the preeminence of antibody as an effector of graft outcome were the seminal studies of Mitchison (8) showing that alloreactivity is transferred by cells but not by serum and Brent et al. (9) likening the allogeneic response to the delayed-type hypersensitivity reaction. The advent and successful use in transplantation of pharmaceutical agents relatively selective for $\mathrm{T}$ cells appeared to resolve the argument, at least for the first $30 \mathrm{yr}$ of clinical transplantation, in favor of cells.

However, today, it would seem more attention is devoted to humoral than to cellular immunity to transplantation. Successful control of acute cellular immunity led to the recognition that the long-term success of organ allografts is threatened mainly by antibody-mediated chronic vascular and interstitial diseases that demonstrably resist the pharmaceutical agents so effective at suppressing cellular immunity. Moreover, today, in subjects treated with immunosuppressive agents, the outcome of transplantation correlates more closely with humoral than with cellular immune responses (10). And, improvements in overall survival, including freedom from cardiovascular disease and cancer, might today depend on finding ways to "fine-tune" immunosuppressive therapy, and for that purpose, donor-specific antibodies might provide a more sensitive and specific index than assays of peripheral $\mathrm{T}$-cell responses. Whether antibodies provide an index that can direct and refine therapeutics is still unknown, but the results of Suciu-Foca et al. (1) and Gloor (11) suggest the answer may be "yes". 
This symposium begins with a paper by Ho et al. (1) from the program headed by Nicole Suciu-Foca at Columbia. This team has over the years provided the most critical, incisive, and independent insight into the involvement of antibodies against donor HLA in the long-term outcome of organ grafts (12). The original work of this group was conducted when transplant immunologists focused almost all attention on $\mathrm{T}$ cells and the small measure of attention directed at antibodies mainly concerned antibodies against structures other than HLA. Now, this group courageously takes a critical look at new methods for detecting and measuring anti-HLA antibodies. Two lessons especially to draw are that (i) the technologies for analysis of antibodies will continue to evolve and (ii) one must continuously ask whether antibodies detected by one or another new technique instruct us about whether grafts will fail and/or why.

The second paper in this symposium originates with Jim Gloor from the Mayo Clinic (11). Jim may have more experience than anyone else in the transplantation of organs into presensitized recipients (including ABO-incompatible organs) and in the diagnosis and management of antibody-mediated rejection. Jim uses this vast experience not just as a platform for speculation but also as a source of information for analysis of what donor-specific antibodies mean and how to treat patients with graft injury caused by those antibodies. Jim's approaches to diagnosis and management are widely emulated by those who care for children and adults with organ transplants, and hence the clinician might do well to carry this paper to rounds.

The third paper in this symposium was submitted by Marilia Cascalho and me (13). Marilia is a B-cell biologist whose work provided key insight into the mechanisms that diversify B cells and maintain Ig levels in blood (14) and link somatic hypermutation in B cells with DNA repair (15). Marilia and I will offer a basic perspective on what donor-specific antibodies might be and what they might mean.

The fourth paper in this symposium is authored by Lori West from Edmonton. Lori pioneered ABO-incompatible transplantation of the heart in infants and children (16). Her experience with these transplants has taught important practical lessons regarding organ allocation and management [e.g., matching for ABO compatibility and even just avoiding incompatibility does not matter for the young (17)]. Perhaps of greater importance however is the lesson that fundamental advances in immunology [e.g., spontaneous tolerance to blood group antigens (18)] and presumably in other fields can emerge from efforts to replace failing organs in the young.

Addressing one aspect of transplantation immunity, the usefulness of evaluating donorspecific antibodies after transplantation, this symposium necessarily neglects some related subjects of equal or greater importance. This symposium does not address the question of how donor-specific antibodies are produced and how production is regulated. Gloor (11) does consider with authority therapeutic approaches to eliminating those antibodies once they are made. Understanding the cellular and molecular basis for allogeneic responses of B cells may allow the development of still more sophisticated and more specific therapeutics, but this subject must await a more focused consideration of B-cell biology. Also put to the side is the question of how donorspecific antibodies injure grafts. This subject has been investigated rather thoroughly over the last $20 \mathrm{yr}$, mainly from the perspective of xenotransplantation (19), but the impact of donor-specific antibodies would seem better suited to a symposium on endothelial cell biology. However, the reader should know that research into the impact of antibodies on organ grafts almost always eventuates the conclusion that depleting or stopping the production of donor-specific antibodies more effectively prevents graft injury than blocking the downstream effector pathways. Knowing the properties of donor-specific antibodies as discussed in the papers in this symposium can only bring us closer to that goal.

\section{References}

1. Ho eK, Vasilescu ER, Vlad G, Marboe CC, Addonizio LJ, Suciu-Foca N. HLA antibodies in pediatric heart transplantation. Pediatr Transplant 2011: 15: 458-464.

2. SNELL GD. The genetics of transplantation. J Natl Cancer Inst 1953: 14: 691-700; discussion, 701-704.

3. Terasaki PI, Marchioro TL, Starzl TE. Sero-typing of human lymphocyte antigens: Preliminary trials on long-term kidney homograft survivors. In: Russell PS, ed. Histocompatibility Testing. Washington, DC: National Research Council, 1965: pp 83-96.

4. Patel R, Terasaki PI. Significance of the positive crossmatch test in kidney transplantation. N Engl J Med 1969: 280: 735-739.

5. Stetson CA. The role of humoral antibody in the homograft reaction. Adv Immunol 1963: 3: 97-130.

6. Koch CA, Khalpey ZI, Platt JL. Accommodation: Preventing injury in transplantation and disease. J Immunol 2004: 172: 5143-5148.

7. Platt JL. New directions for organ transplantation. Nature 1998: 392: 11-17.

8. Mitchison NA. Passive transfer of transplantation immunity. Nature 1953: 171: 267-268.

9. Brent L, Brown J, Medawar PB. Skin transplantation immunity in relation to hypersensitivity. Lancet 1958: 2: 561-564.

10. Terasaki PI. Humoral theory of transplantation. Am J Transplant 2003: 3: 665-673. 


\section{A Symposium on Donor-Specific Antibodies after Transplantation}

11. GLOOR J. The utility of comprehensive assessment of donor specific anti-HLA antibodies in the clinical management of pediatric kidney transplant recipients. Pediatr Transplant (in press).

12. Suciu-Foca N, Reed E, D'Agati VD, et al. Soluble HLA antigens, anti-HLA antibodies, and antiidiotypic antibodies in the circulation of renal transplant recipients. Transplantation 1991: 51: 593-601.

13. Platt JL, Cascalho M. Donor specific antibodies after transplantation. Pediatr Transplant (in press)

14. Cascalho M, Ma A, Lee S, Masat L, Wabl M. A quasimonoclonal mouse. Science 1996: 272: 1649-1652.

15. Cascalho M, Wong J, Steinberg C, Wabl M. Mismatch repair co-opted by hypermutation. Science 1998: 279: 1207-1210.
16. West LJ, Pollock-Barziv SM, Dipchand AI, et al. ABOincompatible heart transplantation in infants. N Engl J Med 2001: 344: 793-800.

17. Dipchand Ai, Pollock Barziv SM, Manlhiot C, West LJ, VANDERVLIET M, McCRINDle BW. Equivalent outcomes for pediatric heart transplantation recipients: $\mathrm{ABO}$-blood group incompatible versus ABO-compatible. Am J Transplant 2009: 10: 389-397.

18. Fan X, Ang A, Pollock-BarZiv SM, et al. Donor-specific B-cell tolerance after ABO-incompatible infant heart transplantation. Nat Med 2004: 10: 1227-1233.

19. Cascalho M, Platt JL. The immunological barrier to xenotransplantation. Immunity 2001: 14: 437-446. 